\title{
Analisa Program Tablet Tambah Darah untuk Ibu Hamil di Kota Bogor
}

\section{Iron Tablet Supplementation Program Analysis for Pregnant Women in Bogor}

\author{
Shabrina Ayu Margirizki* ${ }^{1}$, Sri Sumarmi ${ }^{1}$
}

\begin{abstract}
ABSTRAK
Latar Belakang: Anemia pada ibu hamil dapat berdampak pada kematian janin selama masa kehamilan dan kematian ibu saat melahirkan. Salah satu upaya pemerintah dalam penanganan dan penanggulangan anemia pada ibu hamil tercantum dalam Permenkes RI Nomor 97 tahun 2014, dengan melakukan pendistribusian suplemen tablet tambah darah dan pemberian edukasi gizi.

Tujuan: Tujuan penelitian ini adalah menganalisis ketimpangan melalui pelaksanaan program tablet tambah darah untuk ibu hamil di Kota Bogor.

Metode: Penelitian ini termasuk kedalam penelitian deskriptif kualitatif dan menggunakan metode pengumpulan data wawancara mendalam. Informan utama berjumlah 9 orang, yaitu 1 orang tenaga gizi Dinas Kesehatan Kota Bogor, 4 orang tenaga kesehatan bidan dan gizi puskesmas, dan 4 orang ibu hamil.

Hasil: Hasil penelitian menunjukkan bahwa implementasi program tablet tambah darah untuk ibu hamil di Kota Bogor dilakukan melalui program distribusi tablet tambah darah dan edukasi gizi namun menunjukkan perbedaan pada penerimaan informasi yang diterima ibu hamil di puskesmas dengan cakupan rendah. Kesulitan memahami media yang digunakan tenaga kesehatan gizi ditemukan pada puskesmas dengan cakupan tinggi. Data cakupan tablet tambah darah untuk ibu hamil belum terdata secara aktual dari tenaga kesehatan bidan swasta karena koordinasi yang rendah antara bidan swasta dan pihak pemerintah.

Kesimpulan: Program tablet tambah darah untuk ibu hamil dapat dioptimalkan dengan meningkatkan intensitas komunikasi antara tenaga kedinasan dan tenaga kesehatan bidan swasta untuk menyamakan informasi cakupan, memberikan acuan pokok terkait media konseling dan edukasi yang digunakan oleh tenaga kesehatan dalam proses konseling dan edukasi, dan menetapkan Standar Prosedur Operasional kepada tenaga kesehatan untuk memberikan informasi yang baik dan jelas kepada ibu hamil terkait tablet tambah darah.
\end{abstract}

Kata Kunci: ibu hamil, komunikasi, sumber daya, tablet tambah darah

\section{ABSTRACT}

Background: Anemia in pregnant women may impacting to miscarriage during pregnancy and death on delivery process. One amongst many governments' efforts to cope with anemia on pregnancy mentioned in Permenkes RI No 97 published on 2014 are distributing iron tablet to pregnant women and giving nutritional related education. Those programs done by primary local healthcare center.

Objectives: Objective of this study was to analyze the inequality of iron tablet program for pregnant women through intervention programmes in Kota Bogor.

Methods: This was a descriptive qualitative study. Main informants were 1 nutrition staff in Dinas Kesehatan Kota Bogor, 4 health workers in primary healthcare center, and 4 pregnant women.

Results: Result of study shown that iron tablet implementation program for pregnant women in Kota Bogor was done by using same method but show differences impact of pregnant women in low coverage of primary healthcare center. The difficulties in understanding the media facility was found in high coverage of primary healthcare center. Current data for iron tablet coverage for pregnant women is not the actual data due to lack of coordination between private midwife and government.

Conclusions: Iron tablet program for pregnant women can be optimized by increasing communication 
intensity between private midwife and government to integrate the data, providing standard reference for media facility that used in counseling and education process, and establishing Standard Operational Procedure to every health workers in primary healthcare center to give right and clear explanation about iron tablet to pregnant women.

Keywords: communication, iron tablet, pregnant women, resource

\author{
*Koresponden: \\ shabrinaayu@hotmail.com \\ Shabrina Ayu Margirizki \\ ${ }^{1}$ Departemen Gizi, Fakultas Kesehatan Masyarakat, Universitas Airlangga, Kampus C Mulyorejo, 60115, \\ Surabaya, Jawa Timur, Indonesia
}

\title{
PENDAHULUAN
}

Anemia didefinisikan sebagai penurunan satu atau lebih parameter sel darah merah: konsentrasi hemoglobin, hematocrit atau jumlah sel darah merah(Oehadian, 2012).Riskesdas tahun 2018 menggambarkan bahwa anemia pada ibu hamil sebanyak 48,9\% (Kementerian Kesehatan Republik Indonesia, 2018).Menurut kriteria WHO anemia adalah kadar hemoglobin dibawah $11 \mathrm{~g} \%$ pada wanita hamil (World Health Organization, 2011). Anemia dapat disebabkan oleh dua faktor, yakni penurunan pasokan oksigen ke jaringan dan adanya hipolovemia (pada penderita dengan pendarahan akut dan masif). Kondisi anemia pada ibu hamil memiliki risiko 9 kali lebih besar untuk melahirkan bayi dengan berat badan rendah dibandingkan dengan ibu hamil yang tidak mengalami anemia (Suhartati, 2017)

Selain berdampak pada janin, kondisi kehamilan yang kurang optimal juga dapat berdampak pada ibu, yakni kematian ibu akibat pendarahan saat melahirkan atau perdarahan postpartum (Risnawati, I., Hanung, 2015) Sebagai penyebab kematian ibu, perdarahan postpartum disebabkan oleh rendahnya suplai oksigen dalam darah atau anemia yang dalam kondisi normal berguna untuk kontraksi rahim. Pada kondisi anemia dengan tipisnya suplai oksigen dalam darah, semakin rendah pula kemampuan ibu hamil untuk melakukan kontraksi (Aryani, 2017).

Pada kasus anemia, pemerintah telah mengupayakan penanggulangan masalah anemia pada ibu hamil dengan melakukan pembagian Tablet Tambah Darah (TTD) atau tablet zat besi (Fe). Pemberian TTD sebanyak 90 tablet merupakan salah satu komponen pelayanan kesehatan ibu hamil sebagaimana dijelaskan dalam Profil Kesehatan Republik Indonesia.

Pemberian tablet tambah darah untuk ibu hamil dicantumkan dalam Peraturan Menteri Kesehatan Republik Indonesia Nomor 97 Tahun 2014 Pasal 12 Ayat 4 yang diantaranya menyebutkan bahwa: 1) Pelayanan antenatal terpadu merupakan pelayanan kesehatan komprehensif dan berkualitas yang dilakukan melalui pemberian pelayanan dan konseling kesehatan termasuk stimulasi dan gizi agar kehamilan berlangsung sehat dan janinnya lahir sehat dan cerdas; 2) Melibatkan ibu hamil, suami, dan keluarganya dalam menjaga kesehatan dan gizi ibu hamil, menyiapkan persalinan dan kesiagaan bila terjadi penyulit/komplikasi.

Pemberian Tablet Tambah Darah (TTD) yang diperuntukkan untuk ibu hamil dibagikan sebanyak 90 tablet Fe. Berdasarkan Kementerian Kesehatan Republik Indonesia dijelaskan bahwa 90 butir TTD dibagikan dengan teknis membagikan 10 butir TTD setiap bulan kehamilan.

Upaya Kementerian Kesehatan untuk mengoptimalkan kesehatan ibu hamil tidak hanya dilakukan dengan pemberian suplemen TTD, namun pemerintah juga melaksanakan program pembinaan kesehatan ibu dan reproduksi berupa program Kelas Ibu. Program Kelas Ibu masuk kedalam Rencana Strategis Kementerian Kesehatan Republik Indonesia sebagai salah satu program nasional yang dijadikan indikator peningkatan akses dan kualitas pelayanan kesehatan ibu dan reproduksi.

Dukungan terhadap pelaksanaan program optimalisasi kesehatan ibu hamil juga didukung oleh Pemerintah Kota Bogor yang tertulis dalam Peraturan Wali Kota Bogor Nomor 48 Tahun 2017 yang menyatakan bahwa peran serta masyarakat sangat diperlukan dalam mendukung Percepatan Perbaikan Gizi yang difokuskan pada 1.000 HPK dengan mengikuti Program Perbaikan Gizi Masyarakat, salah satunya adalah pemeriksaan Antenatal Care (ANC) bagi ibu hamil.

Berdasarkan penelitian Purnamasari(Purnamasari, 2016) yang dilakukan di Bogor, menggambarkan prevalensi anemia pada ibu hamil sebesar 63,63\% sedangkan cakupan tablet tambah darah untuk ibu hamil mencapai 96,92\%, dengan target capaian cakupan sebesar $85 \%$. Perbedaan antara capaian, target capaian, dan prevalensi anemia pada ibu hamil tersebut memberikan gambaran bahwa adanya ketimpangan antara kebijakan dan implementasi kebijakan. Permasalahan ketimpangan tersebut tentu tidak lepas dari pelaksana program atau kebijakan. Ketimpangan antara kebijakan dan implementasi dari pelaksana kebijakan tergambar pada penelitian Megalia(Megalia, 2011) yang menyatakan bahwa rendahnya kompetensi dan produktivitas Pegawai Negeri Sipil (PNS) mengakibatkan sulit tercapainya efisiensi dan efektifitas dalam penyelenggaraan pemerintahan. Faktor penyebab utama hal tersebut adalah kesiapan SDM, manajemen 
Diklat, dan lembaga Diklat. Ketimpangan antara kebijakan dan implementasi kebijakan turut terbukti melalui penelitian Anggraeni(Anggraeni, 2016) bahwa cakupan Fe di Puskesmas Slawi pada tahun 2016 hanya mampu mencapai $75 \%$ dari target SPM $80 \%$.

Penelitian ini memiliki tujuan untuk menganalisis ketimpangan antara nilai cakupan tablet tambah darah untuk ibu hamil dan nilai anemia pada ibu hamil dengan pengamatan pada pelaksanaan programprogram intervensi anemia ibu hamil oleh Dinas Kesehatan Kota Bogor dan Puskesmas.

\section{METODE}

Pada penelitian ini peneliti menggunakan pendekatan studi kualitatif dengan cara pemilihan sampel melalui pemilihan sampel bertujuan pada informan perwakilan Dinas Kesehatan Kota Bogor dan tenaga kesehatan puskesmas, dan pemilihan sampel acak pada responden ibu hamil. Data dikumpulkan menggunakan wawancara mendalam (in depth interview) di dua puskesmas berbeda. Puskesmas A dengan cakupan TTD tertinggi di Kota Bogor tahun 2017 sebesar 101,27\% dan Puskesmas B dengan cakupan TTD terrendah di Kota Bogor tahun 2017 sebesar 53,22\%. Teori yang digunakan merupakan Teori George Edward III (Edwards III, 1980) yang merupakan teori implementasi kebijakan dan program hasil kebijakan. Teori ini menyatakan bahwa terdapat empat variabel utama yang mampu mempengaruhi pelaksanaan implementasi kebijakan dan program, yakni Komunikasi, Sumber Daya, Disposisi, dan Struktur Birokrasi. Keempat variabel tersebut bersifat saling mempengaruhi sehingga apabila ditemukan ketimpangan pada salah satu variabel maka dapat menghambat implementasi program.

Model analisis data yang digunakan adalah teknik analisis data interaktif kualitatif yang menurut Miles dan Huberman dalam Nugrahani (Nugrahani, 2014) merupakan proses klarifikasi dan intepretasi materi linguistik atau visual mengenai aspek implisit atau eksplisit, dan menyusun aspek pemahaman secara terstruktur. Teknik analisis data yang dilakukan adalah dengan melakukan wawancara kepada para informan, kemudian hasil wawancara diinterpretasi kedalam bentuk kalimat berupa transkrip hasil wawancara yang kemudian skrip hasil wawancara akan digunakan sebagai hasil penelitian. Proses triangulasi data dalam penelitian ini dilakukan menggunakan cara triangulasi metode dengan pemberian pertanyaan terstruktur sehingga kebenaran yang diberikan informan dapat dipastikan. Informan dalam penelitian ini merupakan 1 orang tenaga kedinasan, 1 tenaga kesehatan bidan puskesmas dan 1 tenaga kesehatan puskesmas, dan 2 orang ibu hamil dari masing- masing puskesmas yang diteliti. Keterlibatan informan dalam penelitian ini sudah diketahui dan mendapatkan persetujuan dari komisi etik dengan nomor sertifikat etik 1174-KEPK.

\section{HASIL DAN PEMBAHASAN}

\section{Karakteristik Informan}

Tabel 1. Karakteristik Informan

\begin{tabular}{|c|c|c|c|c|c|}
\hline No & Inisial & Usia & Jenis Kelamin & Pendidikan & Peran \\
\hline 1 & $\mathrm{E}$ & 46 & $\mathrm{P}$ & Strata 1 & $\begin{array}{c}\text { Perwakilan Dinas } \\
\text { Kesehatan Kota Bogor }\end{array}$ \\
\hline 2 & I & 48 & $\mathrm{P}$ & Diploma III & Bidan Puskesmas A \\
\hline 3 & $\mathrm{R}$ & 29 & $\mathrm{P}$ & Strata I & Tenaga Gizi Puskesmas A \\
\hline 4 & $\mathrm{D}$ & 32 & $\mathrm{P}$ & Strata I & Bidan Puskesmas B \\
\hline 5 & M & 50 & $\mathrm{P}$ & Diploma III & Tenaga Gizi Puskesmas B \\
\hline 6 & $\mathrm{Y}$ & 37 & $\mathrm{P}$ & SMA & Ibu Hamil Puskesmas A \\
\hline 7 & A & 31 & $\mathrm{P}$ & Diploma III & Ibu Hamil Puskesmas A \\
\hline 8 & $\mathrm{~L}$ & 30 & $\mathrm{P}$ & SMA & Ibu Hamil Puskesmas B \\
\hline 9 & $\mathrm{~K}$ & 28 & $\mathrm{P}$ & SMA & Ibu Hamil Puskesmas B \\
\hline
\end{tabular}

\section{Cakupan TTD di Kota Bogor}

Dalam tiga tahun terakhir cakupan TTD di Kota Bogor berada diatas nilai rata-rata cakupan nasional. Tingginya nilai cakupan ini disebabkan oleh adanya dukungan dan keterlibatan masyarakat dalam program- program terkait TTD yang dicanangkan dalam Peraturan Walikota Bogor Nomor 48 Tahun 2017 Pasal 4 Ayat 1 yang berbunyi "Germas Kota Bogor dilakukan melalui tindakan promotif dan preventif hidup sehat kepada warga Kota Bogor yang pelaksanaannya dilakukan oleh seluruh masyarakat dan komponen masyarakat.". 


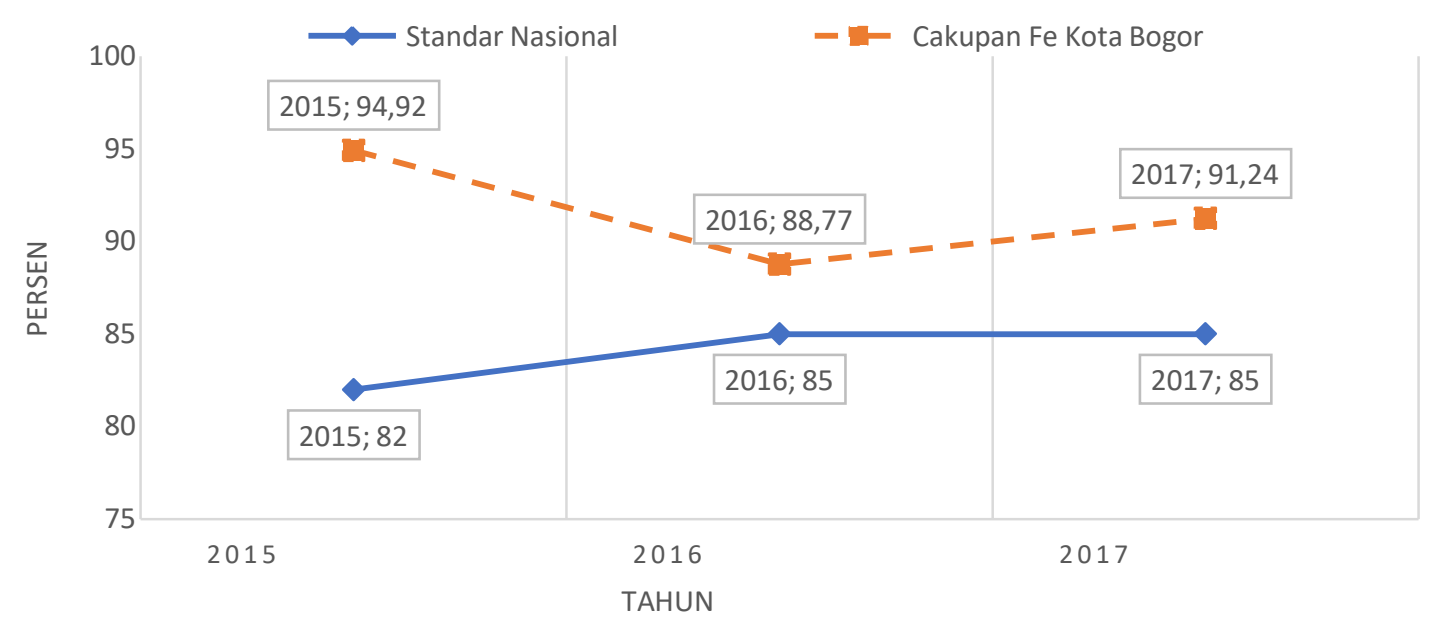

Gambar 1. Cakupan TTD di Kota Bogor 2015-2017

\section{Ragam Program Terkait TTD untuk Ibu Hamil}

Dalam penelitian ini didapatkan hasil bahwa terdapat 7 program terkait TTD yang dilaksanakan di Kota Bogor. Empat dari tujuh program yang memiliki keterkaitan dengan TTD dilaksanakan dengan melibatkan tokoh masyarakat maupun komponen dalam masyarakat. Ketujuh program-program terkait TTD tersebut adalah; Pemeriksaan Ibu Hamil; merupakan program rutin yang termasuk kedalam rangkaian antenatal care, melibatkan bidan, tenaga gizi, dan tenaga kader kesehatan, dalam program ini bersama dengan pemeriksaan ibu hamil TTD turut didistribusikan kepada ibu hamil. Program Kelas Ibu; merupakan program edukasi kesehatan bagi ibu dan calon ibu yang berisi himbauan mengenai cara untuk menjaga kesehatan kehamilan optimal hingga cara untuk menjaga kesehatan ibu dan anak pasca melahirkan. Program ini dilaksanakan secara rutin sebanyak 4 kali dalam setahun di puskesmas atau di posyandu ibu hamil.

Program Kelas Ibu merupakan program nasional dari Kementerian Kesehatan Republik Indonesia. Program Stiker Pemantauan Minum TTD 90 Tablet; merupakan program upaya pemantauan konsumsi TTD ibu hamil dengan menempelkan stiker pemantauan yang diberikan tanda centang apabila ibu hamil sudah mengonsumsi TTD, stiker ini dilekatkan pada buku kontrol ibu hamil sehingga memudahkan pemantauan yang dilakukan oleh bidan. Penelitian mengenai pelaksanaan program kelas ibu hamil dilakukan oleh Andriani (Andriani, 2016) di Kabupaten Banyuwangi yang menggambarkan bahwa pengadaan kelas ibu hamil mampu menurunkan tingkat anemia pada ibu hamil namun tidak signifikan secara statistik, yakni ibu hamil yang mengikuti kelas ibu berisiko anemia 0,5 kali lebih rendah dibandingkan ibu hamil yang tidak mengikuti kelas ibu hamil. Pada penelitian Agustiningsih (Agustiningsih, 2017) menggambarkan bahwa pada ibu hamil yang mengikuti kelas ibu hamil tidak mengalami anemia, sedangkan ibu hamil yang tidak mengikuti kelas ibu hamil 30,0\% diantaranya mengalami anemia.

Program Nga Emas; merupakan program yang bertujuan untuk menjaga keselamatan kelahiran bayi yang ditujukan untuk ibu hamil. Pelaksanaan program ini melibatkan ibu hamil, bidan, dan tenaga gizi puskemas. Dalam program ini TTD disinggung dalam bentuk himbauan konsumsi TTD untuk ibu hamil.

Program Forum Peduli Kesehatan Ibu dan Anak; merupakan forum yang melibatkan tokoh-tokoh masyarakat yang peduli terhadap kesehatan ibu dan anak. Pada program ini TTD disinggung dalam bentuk himbauan konsumsi TTD untuk ibu hamil.

Program Forum Motivator KIA: merupakan program yang ditujukan unutk kader kesehatan posyandu, program ini berfungsi untuk memaksimalkan tugas kader kesehatan dalam mengingatkan ibu hamil untuk mengonsumsi TTD sebagai salah satu upaya untuk menjaga kesehatan kehamilan. Kader kesehatan yang tergabung dalam Dinas Kesehatan Kota Bogor berjumlah kurang lebih

950 orang, dengan masing-masing minimal 5 orang kader kesehatan di setiap posyandu. Dalam penelitian Wahyuni menjelaskan bahwa Keterlibatan kader posyandu dalam pendampingan ibu hamil untuk mengonsumsi tablet tambah darah mampu meningkatkan tingkat konsumsi TTD ibu.(Wahyuni, 2018)

Program RW Siaga; merupakan program yang bertujuan untuk membantu posyandu dan puskesmas dalam pendataan ibu hamil di lingkup RW dan sebagai garda terdepan dalam hal kesiapan 
dan kesiagaan persalinan ibu hamil. Dalam program ini TTD disinggung dalam bentuk himbauan untuk ibu hamil dalam mengonsumsi TTD sebagai salah satu upaya untuk menjaga kesehatan kehamilan. Program ini juga melibatkan keluarga inti dari ibu hamil sehingga mampu memberikan dukungan untuk mengkonsumsi TTD, sebab dukungan suami dan keluarga mempengaruh ibu hamil dalam mengkonsumsi TTD (Rabiatunnisa, 2017)

\section{Kendala Pelaksanaan Program Terkait TTD untuk Ibu Hamil}

Berdasarkan analisis implementasi program menggunakan teori George Edward III(Edwards III, 1980), maka didapatkan hasil bahwa dalam pelaksanaan program-program terkait TTD di Kota Bogor memiliki kendala seperti pada Tabel 2.

Tabel 2. Matriks Analisis Kendala Pelaksanaan Program Terkait TTD di Kota Bogor

\begin{tabular}{|c|c|c|c|c|c|c|c|c|c|c|c|c|c|}
\hline \multirow[b]{2}{*}{$\begin{array}{l}\mathbf{N} \\
\mathbf{o .}\end{array}$} & \multirow[b]{2}{*}{ Variabel } & \multirow[b]{2}{*}{$\begin{array}{c}\text { Subvaria } \\
\text { bel }\end{array}$} & \multicolumn{4}{|c|}{ Pelaksana } & \multicolumn{7}{|c|}{ Program } \\
\hline & & & $\begin{array}{c}\text { Dinas } \\
\text { Kesehat } \\
\text { an }\end{array}$ & $\begin{array}{c}\text { Bida } \\
\text { n } \\
\text { Swas } \\
\text { ta } \\
\end{array}$ & $\begin{array}{c}\text { Puskes } \\
\text { mas A }\end{array}$ & $\begin{array}{c}\text { Puskes } \\
\text { mas B }\end{array}$ & 1 & 2 & 3 & 4 & 5 & 6 & 7 \\
\hline \multirow[t]{3}{*}{1} & Komuni & Transmisi & + & - & + & + & - & - & + & + & + & + & + \\
\hline & kasi & $\begin{array}{l}\text { Kejelasan } \\
\text { Komunik } \\
\text { asi }\end{array}$ & + & - & + & + & - & - & + & + & + & + & + \\
\hline & & $\begin{array}{l}\text { Konsisten } \\
\text { si }\end{array}$ & + & - & + & + & + & + & + & + & + & + & + \\
\hline \multirow[t]{3}{*}{2} & $\begin{array}{l}\text { Sumber } \\
\text { Daya }\end{array}$ & $\begin{array}{l}\text { Staf } \\
\text { Informasi }\end{array}$ & + & + & + & + & + & + & + & + & + & + & + \\
\hline & & $\begin{array}{l}\text { Kewenan } \\
\text { gan }\end{array}$ & + & + & + & + & + & + & + & + & + & + & + \\
\hline & & $\begin{array}{l}\text { Fasilitas } \\
\text { Kognisi }\end{array}$ & + & + & - & + & + & + & + & + & + & + & + \\
\hline 3 & Disposisi & $\begin{array}{l}\text { Arahan } \\
\text { dan } \\
\text { Tanggapa } \\
\mathrm{n} \\
\text { Pelaksana } \\
\text { Instensita } \\
\text { s Respon }\end{array}$ & + & + & + & + & + & + & + & + & + & + & + \\
\hline 4 & $\begin{array}{l}\text { Struktur } \\
\text { Birokrasi }\end{array}$ & $\begin{array}{l}\text { Penyebar } \\
\text { an } \\
\text { Tanggun } \\
\text { g Jawab }\end{array}$ & + & + & + & + & + & + & + & + & + & + & + \\
\hline
\end{tabular}

$\begin{array}{lll}+ & = & \text { berjalan dengan baik / tidak ditemukan kendala } \\ - & = & \text { berjalan dengan tidak baik / ditemukan kendala }\end{array}$

Keterangan Program:

1. Program Pemeriksaan Ibu Hamil

2. Kelas Ibu

3. Stiker Pemantauan Minum TTD 90 Tablet

4. Nga Emas

5. Forum Peduli Kesehatan Ibu dan Anak

6. Forum Motivator KIA

7. RW

Siaga

Pada tabel 2 dapat terlihat bahwa pelaksanaan program terkait TTD di Kota Bogor memiliki kendala pada variabel Komunikasi tingkat Bidan Swasta, Transisi dan Kejelasan Komunikasi di Tingkat Program Pemeriksaan Ibu Hamil dan Kelas Ibu, dan pada variabel Sumber Daya Fasilitas di Tingkat Puskesmas A. Sedangkan pada puskesmas B tidak ditemukan kendala pada tingkat tenaga kesehatan dalam melaksanakan 
program. Kendala komunikasi pada tingkat bidan swasta terjadi karena tidak adanya penyamaan data terkait cakupan TTD yang didistribusikan oleh bidan swasta kepada ibu hamil, sementara itu bidan swasta tidak hanya mendistribusikan TTD yang diberikan oleh pemerintah namun bidan swasta turut mendistribusikan TTD komersial. Tidak terintegrasinya sistem pendataan tersebut mengakibatkan data cakupan TTD yang dimiliki oleh Kota Bogor saat ini belum mampu mewakili keseluruhan ibu hamil yang mendapatkan TTD, baik TTD yang diberikan oleh pemerintah maupun TTD komersial. Pendataan mengenai cakupan TTD komersial yang dilakukan oleh bidan swasta pernah tercatat namun pencatatan tidak berlanjut sehingga konsistensi informasi yang diberikan oleh bidan swasta pada Dinas Kesehatan Kota Bogor tidak konsisten. Namun dengan adanya kendala komunikasi ini, validitas data cakupan TTD untuk ibu hamil di Kota Bogor belum dapat dipastikan. Kendala pada variabel komunikasi dengan subvariabel transisi dan kejelasan informasi ditemukan dalam program Pemberian TTD untuk Ibu Hamil dan Kelas Ibu. Pada kedua program ini, ibu hamil diberikan edukasi mengenai cara menjaga kesehatan selama kehamilan termasuk didalamnya adalah edukasi pencegahan anemia dan anjuran konsumsi TTD. Timpangnya informasi yang diterima oleh sasaran program digambarkan pada hasil wawancara dengan ibu hamil di Puskesmas B yang menyatakan bahwa,

"TTD diminum saat darah rendah, kalo kebanyakan entar darah tinggi". (Ibu L, komunikasi personal, 7 November 2018)

Kurang tepatnya pemahaman ibu hamil terhadap TTD dan anemia menggambarkan bahwa ternyata transmisi kejelasan informasi mengenai anemia dan TTD tidak sampai secara tepat kepada sasaran program yakni ibu hamil, meski sebenarnya informasi mengenai anemia dan TTD dimiliki dengan baik oleh para tenaga kesehatan sebagai penyampai informasi. Pada penelitian Fitria(Fitria, 2018) menggambarkan bahwa ada hubungan antara pengetahuan ibu hamil tentang tablet $\mathrm{Fe}$ dan anemia. Penelitian Kafiyanti(Kafiyanti, 2016) menggambarkan bahwa terdapat hubungan antara pengetahuan tentang anemia terhadap kejadian anemia pada ibu hamil.

Terdapat perbedaan pemahaman pada ibu hamil di Puskesmas A yang kedua informan ibu hamil mampu menjelaskan dengan tepat mengenai pemahaman terkait TTD dan anemia.

"TTD itu untuk menambah darah dan mencegah pendarahan saat melahirkan" (Ibu A, komunikasi personal, 5 November 2018)

Kendala berikutnya ditemukan pada variabel Sumber Daya subvariabel Fasilitas di tingkat Puskesmas A. Kendala ini ditemukan sebab tenaga gizi di Puskesmas A menyatakan bahwa terdapat kesulitan pada saat melakukan sesi Konseling Informasi dan Edukasi (KIE) sebab pada media lembar balik tidak terdapat narasi singkat yang dapat digunakan sebagai petunjuk untuk menjelaskan gambar yang terdapat pada lembar balik. Tenaga kesehatan gizi mengungkapkan bahwa tidak adanya narasi singkat pada lembar balik dikhawatirkan dapat meningkatkan resiko kesalahan tafsir dalam proses KIE. Berdasarkan teori George Edward III(Edwards III, 1980) sumber daya (manusia, materil, dan metode) yang mumpuni mampu mengoptimalkan pelaksanaan program. Pada tingkat pelaksana tenaga kesehatan di Puskesmas B tidak ditemukan kendala, tenaga kesehatan menuturkan bahwa tidak menemukan kesulitan dalam penggunaan media KIE selama proses pelaksanaan program.

\section{Potensi Positif Pelaksanaan Program Tablet Tambah Darah untuk Ibu Hamil}

Potensi positif dianalisis melalui keempat variabel yang dianalisis yakni Komunikasi, Sumber Daya, Disposisi dan Struktur Birokrasi. Pada variabel Komunikasi, potensi positif komunikasi antara tenaga kesehatan dan ibu hamil dapat diperbaiki dengan mengoptimalkan komunikasi antara kader kesehatan dan ibu hamil. Hal ini dilakukan untuk membantu tenaga kesehatan dalam memberikan penjelasan ulang mengenai kesehatan kehamilan dasar yang mencakup anemia dan tablet tambah darah melalui pendekatan personal kepada ibu hamil, dengan hasil akhir meratanya pengetahuan ibu terhadap anemia dan tablet tambah darah. Dalam penelitian Darmawansyih (Darmawansyih, 2017) menerangkan bahwa ada hubungan antara pengetahuan ibu hamil dengan kejadian anemia, maka optimalisasi komunikasi kepada ibu hamil dinilai perlu untuk dilakukan.

Pada variabel Sumber Daya, potensi positif yang dimiliki adalah jumlah kader kesehatan yang merata sehingga apabila kader kesehatan diberikan pengetahuan yang memadai mengenai kesehatan kehamilan dasar sehingga mampu menyebarluaskan pengetahuan kehamilan kepada ibu hamil. Potensi positif lainnya juga ditemukan pada sumber daya informasi. Sumber daya informasi yang dimiliki oleh setiap puskesmas sudah mampu memenuhi kebutuhan dalam pelaksanaan program, namun dapat dioptimalkan apabila informasi yang dimiliki memiliki acuan utama dalam penyampaian informasi KIE kepada ibu hamil sehingga mampu meminimalisir kesalahan tafsir media KIE oleh tenaga kesehatan. 
Dalam penelitian Asyirah (Asyirah, 2012) menyatakan bahwa frekuensi ANC memiliki pengaruh yang tinggi terhadap kejadian anemia, maka sumber daya yang mendukung kelancaran ANC merupakan hal yang perlu diperhatikan. Latar belakang pendidikan, pekerjaan, paritas, dan pengetahuan ibu hamil yang berbeda dapat disesuaikan dengan penyampaian KIE yang baik dalam proses ANC (Ariesta, R., Naufalia, A., 2016)

Pada variabel disposisi, dengan tidak adanya kendala pada variabel ini mampu menggambarkan bahwa tenaga kesehatan yang terlibat dalam program TTD di Kota Bogor mampu menjalankan tugas tanpa adanya kecenderungan. Tenaga kesehatan yang netral dapat menjadi potensi yang baik apabila tenaga kesehatan mampu mengoptimalkan kinerja saat melakukan proses KIE kepada ibu hamil, sehingga dapat meningkatkan pemahaman ibu hamil terhadap anemia dan TTD.

Pada variabel struktur birokrasi, dengan kondisi struktur birokrasi yang mudah dan tidak menyulitkan ibu hamil dalam mendapatkan TTD. Hal ini mampu menjadi nilai tambah yang dapat dijelaskan saat mengajak ibu hamil untuk turut serta dalam program TTD, sehingga nilai cakupan TTD ibu hamil dapat meningkat. Penelitian Su'udi menyatakan bahwa peningkatan pemanfaatan pelayanan kesehatan dapat disebabkan oleh optimalnya kegiatan puskesmas, tepatnya sosialisasi dan sasaran ke masyarakat yang tepat (Su'udi, 2017)

\section{KESIMPULAN}

Dalam penelitian ini dapat ditarik kesimpulan bahwa ragam program terkait TTD yang dilaksanakan di Kota Bogor sudah dilaksanakan sesuai dengan Perwali yang berlaku dan arahan program nasional yang sedang berjalan. Terkait data cakupan TTD belum sepenuhnya mencakup seluruh ibu hamil yang melakukan pengecekan kehamilan ke bidan swasta. Informasi yang diterima oleh ibu hamil megenai TTD dan anemia tidak merata, pada puskesmas dengan cakupan TTD tinggi pemahaman mengenai TTD dan anemia berada pada kondisi baik, sedangkan pada puskesmas dengan cakupan TTD rendah pemahaman mengenai TTD dan anemia berada pada kondisi tidak baik. Fasilitas lembar balik tidak memiliki acuan narasi yang dapat digunakan untuk membantu tenaga gizi dalam melaksanakan KIE.

\section{AKCNOWLEDGMENT}

Peneliti mengucapkan terima kasih banyak kepada Dinas Kesehatan Kota Bogor beserta seluruh tenaga kesehatan tingkat puskesmas dan pasien yang telah berpartisipasi guna kelancaran penelitian, serta terima kasih kepada dosen pembimbing atas arahan, nasihat, dan bimbingan yang telah diberikan.

\section{DAFTAR PUSTAKA}

Agustiningsih, M. . (2017) Efektifitas Program Pembelajaran Kelas Ibu Hamil terhadap Pengetahuan Gizi, Status Anemia, KEK, dan BBLR di Kecamatan Grogol Kabupaten Sukoharjo. Universitas Muhammadiyyah Surakarta.

Andriani, Y. (2016) Efektivitas Kelas Ibu Hamil terhadap Pencegahan Anemia Gravidarium di Kabupaten Banyuwangi. Universitas Sebelas Maret Surakarta.

Anggraeni, I. E. (2016) 'Hubungan Tingkat Kepatuhan Ibu Hamil dalam Konsumsi Tablet Fe dengan Kejadian Anemia', Jurnal Ilmu dan Teknologi Kesehatan, 7(2), pp. 80-92.

Ariesta, R., Naufalia, A., M. (2016) 'Hubungan Karakteristik Ibu Hamil dengan Kepatuhuan Mengkonsumsi Tablet Tambah Darah', Jurnal Obstretika Scientia, 4(1), pp. 381-400.

Aryani, F. (2017) Hubungan Anemia Pada Saat Kehamilan Dengan Kejadian Perdarahan Postpartum Di RSUD Panembahan Senopati Bantul. Uniersitas Aisyiyah Yogyakarta.

Asyirah, S. (2012) Faktor-faktor yang Berhubungan dengan Anemia pada Ibu Hamil di Wilayah Kerja Puskesmas Bajeng Kecamatan Bajeng Kabupaten Gowa 2012. Universitas Indonesia.

Darmawansyih (2017) 'Hubungan Kepatuhan Konsumsi Tablet Fe Terhadap Kejadian Anemia pada Ibu Hamil di Kecamatan Patallassang Kabupaten Gowa Tahun 2016', Alami Journal, 1(1), pp. 51-59.

Edwards III, G. C. (1980) Implementing Public Policy. Washington D.C.: Congressional Quarterely Press.

Fitria, N. E. (2018) Hubungan Pengetahuan Ibu Hamil Tentang Tablet Fe dengan Kejadian Anemia, Jurnal Endurance.

Kafiyanti, N. (2016) Hubungan Tingkat Pengetahuan Ibu Hamil dengan Kejadian Anemia pada Ibu Hamil Trimester III di Puskesmas Jetis Kota Yogyakarta. Universitas Aisyiyiah Yogyakarta. Kementerian Kesehatan Republik Indonesia (2018) Hasil Utama Riskesdas 2018. Jakarta.

Megalia, R. (2011) 'Manajemen Peningkatan Kompetensi Aparatur: Studi tentang Implementasi Kebijakan Reformasi Sumber Daya Manusia pada Badan Pendidikan dan Pelatihan di Indonesia', 4(31), pp. 259- 286.

Nugrahani, F. (2014) Metode penelitian Kualitatif dalam Penelitian Pendidikan Bahasa. Solo: Cakra 
Books. Oehadian, A. (2012) 'Pendekatan Klinis dan Diagnosis Anemia', Cermin Dunia Kedokteran, 39(6), pp. 407-

412.

Purnamasari, G. (2016) 'Hubungan pengetahuan dan sikap terhadap kepatuhan ibu hamil dalam mengkonsumsi tablet Fe di Puskesmas Bogor Tengah', Jurnal Kebidanan dan Ilmu Kesehatan, 3(3), pp. 49-63.

Rabiatunnisa (2017) 'Hubungan Dukungan Suami dengan Kepatuhan Konsumsi Tablet Fe pada Ibu Hamil Trimester III di Puskesmas Wirobrajan Kota Yogyakarta’, Jurnal Medika Respati, 12(4), pp. 3950.

Risnawati, I., Hanung, A. (2015) 'Dampak Anemia Kehamilan Terhadap Perdarahan Post Partum', Jurnal Ilmu Keperawatan dan Kebidanan, 6(3), pp. 57-67.

Su'udi, A. (2017) 'Pemanfaatan Pelayanan Kesehatan Sasaran Program Jaminan Tabalong Sehat di Kabupaten Tabalong Kalimantan Selatan', Jurnal Penelitian dan Pengembangan Pelayanan Kesehatan, 1(2), pp. 102-112.

Suhartati, S. (2017) 'Hubungan Anemia Pada Ibu Hamil dengan Kejadian Bayi Berat Lahir Rendah di Wilayah Kerja Puskesmas Tanta Kabupaten Tabalong Tahun 2016', Dinamika Kesehatan, 8(1), pp. 4554.

Wahyuni, S. (2018) 'Efektifitas Pendampingan Minum Tablet Tambah Darah (TTD) oleh Kader Posyandu Terhadap Peningkatan Kadar Hb Ibu Hamil di Puskesmas Kota Palangka Raya', Jurnal Surya Medika, 3(2), pp. 82-94.

World Health Organization (2011) Haemoglobin concentrations for the diagnosis of anaemia and assessment of severity. 